\title{
Ostre zatrucia u dzieci i młodzieży
}

\section{(Acute poisonings in children and adolescents)}

\author{
K Osmałek ${ }^{1, A, D}, M$ Liniarski $^{1, F}$, Z Kopański $^{1,2, E}$, L Zimnoch ${ }^{1, B, C}$, S Dyl ${ }^{1, B}$, J Rowiński ${ }^{1, E}$, \\ W Uracz ${ }^{1, B}$
}

1. Collegium Masoviense - Wyższa Szkoła Nauk o Zdrowiu

2. Wydziału Nauk o Zdrowiu Collegium Medicum Uniwersytet Jagielloński

\begin{abstract}
The article summarizes the epidemiology of acute poisonings in children and adolescents. Clinical symptoms are presented with particular focus on the characteristics of toxidromes. Toxidromes characteristic for selected substances are also summarized. Diagnostic management and the importance of toxicological screening are discussed. The authors highlight that acute poisoning is a life-threatening event and requires appropriate emergency rescue measures already at the pre-hospitalization stage; therefore, the role of medical rescue service workers upon the first contact with the casualty is is very important. Basic principles of rescue procedures and the importance of antidotes are discussed, including antidotes at the disposal of Medical Rescue Teams.
\end{abstract}

Key words - children and adolescents, acute poisonings, epidemiology, clinical symptoms (toxidromes), treatment, antidotes.

Streszczenie - Autorzy scharakteryzowali epidemiologie ostrych zatruć występujących u dzieci i młodzieży. Przedstawili objawy kliniczne, zwracając uwagę na charakterystykę toksydromów. Omówili toksydromy dla wybranych substancji. Scharakteryzowali diagnostykę zatruć i znaczenie toksykologicznych badań przesiewowych. Podkreślili, że ostre zatrucie jest stanem zagrożenia życia i wymagają odpowiedniego postępowania ratowniczego już w opiece przedszpitalnej, dlatego tak ważna jest rola ratownika medycznego w kontakcie z osobą poszkodowaną. Omówili podstawowe zasady działań ratowniczych, oraz znaczenie odtrutki, w tym odtrutki, którymi dysponują Zespoły Ratownictwa Medycznego.

Słowa kluczowe - dzieci i młodzież, ostre zatrucia, epidemiologia, objawy kliniczne (toksydromy), leczenie, odtrutki.

Wkład poszczególnych autorów w powstanie pracy - A-Koncepcja i projekt badania, B-Gromadzenie i/lub zestawianie danych, C-Analiza i interpretacja danych, D-Napisanie artykułu , E-Krytyczne zrecenzowanie artykułu, F-Ostateczne zatwierdzenie artykułu

Adres do korespondencji — Prof. dr Zbigniew Kopański, Collegium Masoviense - Wyższa Szkoła Nauk o Zdrowiu, Żyrardów, ul. G. Narutowicza 35, PL-96-300 Żyrardów, e-mail: zkopanski@o2.pl

Otrzymano: 20.07.2017.

Zaakceptowano: 25.01.2018.

\section{WYBRANE ZAGADNIENIA Z EPIDEMIOLOGII}

W Polsce brak jest usystematyzowanych badań epidemiologicznych określających problem zatruć występujących u dzieci. Szacuje się, że około 10\% dzieci hospitalizowanych, trafia do szpitala z powodu ostrych zatruć. Liczba dzieci leczona ambulatoryjnie z powodu ostrych zatruć wynosi przy ocenie szacunkowej107/100 000 populacji w wieku 0-17 lat.
Najczęściej zatruciom podlegają dzieci w wieku 1-5 lat, a więc w okresie kiedy dziecko zaczyna dopiero poznawać otoczenie, nie znając jeszcze grożącego mu niebezpieczeństwa. Do 5. r.ż. z reguły są to zatrucia przypadkowe np. wskutek przypadkowego spożycia łatwo dostępnego leku. Tak jest prawie u 50\% dzieci ulegających zatruciu w tym wieku.[45]

Z kolei u dzieci starszych ( w okresie dojrzewania) najczęściej zatrucia ( $90 \%$ wszystkich przypadków) są spowodowane próbami samobój- 
czymi. Najczęściej próby samobójczych zatruć podejmują dziewczynki w wieku 12-14 lat.

Czy to w przypadku przypadkowego, czy to samobójczego zatrucia podkreśla się, że 90\% zatruć następuje w domu.

Zgony spowodowane ostrymi zatruciami spowodowane są najczęściej spożyciem alkoholi niespożywczych (metanol, glikol etylenowy), opiatów (heroina, opioidowe leki przeciwbólowe), substancji psychoaktywnych (kokaina, amfetamina, dopalacze), tlenkiem węgla, paracetamolem, salicylanami, lekami kardiologicznymi i psychotropowymi. [1-9]

\section{OBRAZ KLINICZNY ZATRUCIA}

Obraz kliniczny jest uzależniony głównie od rodzaju i ilości spożytej substancji ( często leku). Wstępna, jak również dalsza ocena stanu zatrutego pacjenta ma na celu ustalenie zespołu charakterystycznych objawów klinicznych zwanych toksydromem. Toksydromy można podzielić na opioidowe, sympatomimetyczne, cholinergiczne i antycholinergiczne (tabela 1.) [2-4,10-12].

Tabela 1.Toksydromy, przyczyny, objawy, postepowanie [[2-4,10-12]]

\begin{tabular}{|c|c|c|c|}
\hline $\begin{array}{l}\text { Tok } \\
\text { sy } \\
\text { dro } \\
\text { m }\end{array}$ & Przyczyny & Objawy & Postępowanie \\
\hline $\begin{array}{l}3 \\
\frac{3}{0} \\
\frac{0}{0} \\
\text { O음 }\end{array}$ & $\begin{array}{l}\text { Morfina } \\
\text { Heroina }\end{array}$ & $\begin{array}{l}\text { - } \quad \text { śpiączka, } \\
\text { szpilkowate źrenice, } \\
\text { depresja oddechowa, } \\
\text { bradykardia, } \\
\text { obniżenie wrażliwości } \\
\text { na bodźce }\end{array}$ & $\begin{array}{l}\text { nalokson, } \\
\text { sztuczna } \\
\text { wentylacja }\end{array}$ \\
\hline 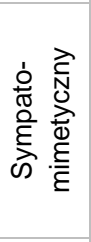 & $\begin{array}{l}\text { Kokaina, } \\
\text { Amfetamina }\end{array}$ & 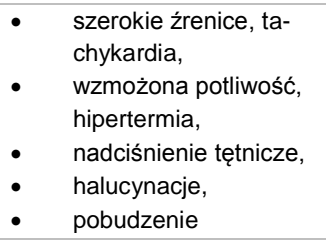 & $\begin{array}{l}\text { sedacja - } \\
\text { benzodiazepiny, } \\
\text { nawodnienie, } \\
\text { chłodzenie } \\
\text { fizyczne }\end{array}$ \\
\hline 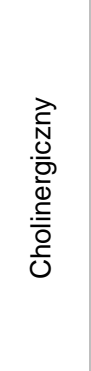 & $\begin{array}{l}\text { Związki } \\
\text { fosforoorga } \\
\text { niczne, } \\
\text { Gazy } \\
\text { bojowe, } \\
\text { Leki na } \\
\text { miastenię } \\
\text { gravis, } \\
\text { Grzyby } \\
\text { muskaryno } \\
\text { we }\end{array}$ & $\begin{array}{l}\text { - } \\
\text { szpilkowate źrenice, } \\
\text { ślinotok, } \\
\text { - } \quad \text { zawienie, } \\
\text { wzmożona sekrecja } \\
\text { oskrzelowa, } \\
\text { - wzrost perystaltyki je- } \\
\text { lit, bezwiedne oddanie } \\
\text { moczu, } \\
\text { - } \\
\text { potliwość, } \\
\text { - } \\
\text { drgawki, } \\
\text { bradykardia }\end{array}$ & $\begin{array}{l}\text { atropina, } \\
\text { pralidoksym lub } \\
\text { obidoksym, } \\
\text { wentylacja } \\
\text { wspomagana }\end{array}$ \\
\hline
\end{tabular}

\section{DIAGNOSTYKA W ZATRUCIACH}

Diagnostyka w zatruciach obejmuje: badanie gazometryczne, oznaczenie jonogramu, glukozy, próby wątrobowe, próby nerkowe i badania toksykologiczne. Wskazaniami do badań toksykologicznych jest głęboka śpiączka, niewyjaśniona kwasica metaboliczna, niewyjaśnione zaburzenia krążenia, niejasny wywiad. Natomiast wskazaniem do ilościowych badań toksykologicznych jest acetaminophen, karbamazepina, digoksyna, luminal, phenytoina, salicylany, teofilina, lit, żelazo, tlenek węgla, etanol, metanol, glikol etylenowy, związki methemoglobinotwórcze.

Do substancji o znacznej toksyczności, aktualnie niewykrywanych w przesiewowych analizach należą powodujące śpiączkę: bromki, chloralhydrat, clonidyna, cyjanki, związki fosforoorganiczne, tetrahydrazolina, działające hypotensyjnie: betablokery blokery kanału wapniowego, klonidyna, kolchicyna. [2-5]

\section{POSTĘPOWANIE MEDYCZNE W ZATRUCIACH}

Postępowanie medyczne w zatruciach dotyczy wielokierunkowego działania ratowniczego (rycina 1.)

Tabela 2. Przykłady toksydromu dla wybranych substancji [2-4,10-12]

\begin{tabular}{|c|c|}
\hline $\begin{array}{l}\text { Substancja } \\
\text { wywołująca } \\
\text { zatrucie }\end{array}$ & Toxidrom \\
\hline $\begin{array}{l}\text { barbiturany i inne } \\
\text { leki uspokajające lub } \\
\text { nasenne }\end{array}$ & $\begin{array}{l}\text { - hypotermia, hypotensja, bradypnoe, } \\
\text { - } \quad \text { ataksja, zamroczenie, śpiączka, } \\
\text { - } \quad \text { pęczopląs, zwężenie lub poszerzenie źrenic, } \\
\text { - }\end{array}$ \\
\hline fenotiazyny & $\begin{array}{l}\text { - } \quad \text { wiotkość, hypotermia, tachykardia, tachyp- } \\
\text { noe, } \\
\text { - } \quad \text { senność śsiączka, drżenia drgawki, } \\
\text { - } \quad \text { objawy pozapiramidowe, ataksja, kręcz } \\
\text { szyi, ułożenie } \\
\text { - odgięciowe, szczękościsk, wysuwanie języ- } \\
\text { ka, } \\
\text { - } \quad \text { zwężenie źrenic }\end{array}$ \\
\hline $\begin{array}{l}\text { preparaty } \\
\text { fosforoorganiczne }\end{array}$ & $\begin{array}{l}\text { - } \quad \text { bradykardia, tachypnoe, } \\
\text { - } \quad \text { przymroczenie, śpiączka, drgawki, drżenia } \\
\text { - } \quad \text { zwężenie, źrenic, łzawienie, zamazane wi- } \\
\text { dzenie, } \\
\text { - } \quad \text { wzmożona potliwość, nadprodukcja śluzu, } \\
\text { - zapach czosnku }\end{array}$ \\
\hline
\end{tabular}




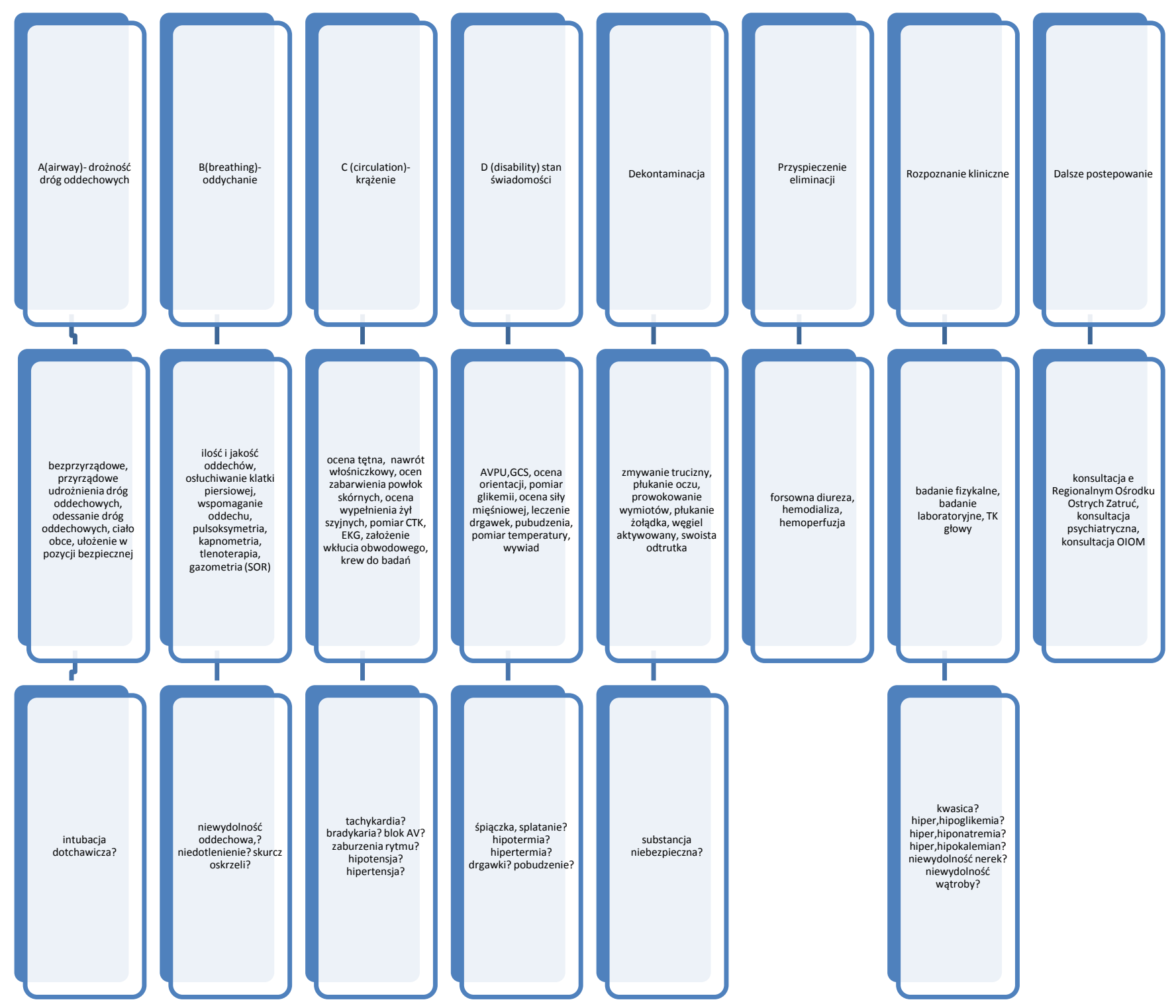

Rycina1. Postępowanie medyczne w zatruciach [[2-4,10-12]] 
Pierwsza pomoc w miejscu zatrucia i w czasie transportu obejmuje [2-4]:

- ocenę stanu ogólnego dziecka,

- zabezpieczenie podstawowych funkcji życiowych,

- usunięcie toksyny jeszcze niewchłoniętej,

- podanie węgla aktywowanego,

- zabezpieczenie materiału do badań toksykologicznych,

- zapewnienie choremu bezpiecznego transportu.

Dziecko nieprzytomne wymaga zapewnienia drożności dróg oddechowych, założenia wkłucia do żyły i jeśli jest zachowany wydolny oddech, przewiezienia w pozycji bezpiecznej do Oddziału Intensywnej Terapii. Należy pamiętać o zebraniu dokładnego wywiadu ( jeśli oczywiście jest to możliwe), przeprowadzeniu dokładnego badania fizykalnego i pobraniu krwi oraz moczu do badań laboratoryjnych ( morfologię krwi obwodowej, stężenie cukru, mocznika, kreatyniny, enzymów wątrobowych, jonogram i gazometrię. Należy również zabezpieczyć próbki krwi (5 $\mathrm{ml}$ na skrzep i $5 \mathrm{ml}$ na heparynę) i moczu na badania toksykologiczne.

Zawsze w przypadku zatrucia należy skontaktować się z Ośrodkiem Toksykologicznym, gdzie można uzyskać informacje o metodach eliminacji trucizny i zasadach postępowania w danym zatruciu [2-4].

Dekontaminacja jest działaniem polegającym na usunięcie niewchłoniętej trucizny, doprowadzając do zmniejszenia jej stężenia w organizmie poszkodowanego. Dekontaminacja może dotyczyć powierzchni ciała (skóry i oczu) ale także przewodu pokarmowego. W szpitalu działania dekontaminacyjne są realizowane pod postacią płukania żołądka, stosowania środków przeczyszczających, płukania jelit, forsownej diureza, wielokrotnych dawek węgla aktywowanego (dializa jelitowa).

Do pozaustrojowych metod eliminacji toksyn należy [2-5]:

1. Dializa otrzewnowa.

2. Hemodializa

3. Hemoperfuzja

4. Transfuzja wymienna

5. Plazmafereza

\section{ECMO}

Jednym ze sposobów leczenia ostrych zatruć jest zastosowanie odtrutki. Mechanizm ich działania dotyczyć może swoistego wiązania toksyną, współzawodnictwa w wiązaniu z receptorem, odwrócenia działania patologicznego toksyny, aktywacji metabolizmu toksyny do związku mniej toksycznego, zablokowania szlaku metabolicznego toksyny do produktu bardziej toksycznego, uzupełnianie kofaktorów wypartych przez toksyny. Jednak tylko w wybranych sytuacjach znaczenie odtrutki staje się pierwszorzędowe. Dotyczy to zatrucia substancjami takimi jak cyjanki, pestycydy fosforoorganiczne, paracetamol, opioidy, benzodiazepiny oraz wczesny etap zatrucia metanolem i glikolem etylenowym. W leczeniu przedszpitalnym jako odtrutki mogą być wykorzystana atropina, flumazenil, nalokson, glukagon, chlorek wapnia, tlen medyczny. [2-4,10-12]

Tabela 3. Odtrutki stosowane w leczeniu przedszpitalnych przy uwzględnieniu mechanizmu działania i dawkowania $[2-4,14]$

\begin{tabular}{|c|c|c|c|}
\hline Odtrutka & $\begin{array}{l}\text { Mechanizm } \\
\text { działania } \\
\text { odtrutki }\end{array}$ & Trucizna & Dawkowanie \\
\hline$\frac{\sqrt[0]{0}}{\frac{0}{0}}$ & $\begin{array}{l}\text { Antagonista } \\
\text { receptorów } \\
\text { cholinergicznych }\end{array}$ & $\begin{array}{l}\text { Związki } \\
\text { fosforoorganic } \\
\text { zne } \\
\text { Karbaminiany } \\
\text { Grzyby } \\
\text { muskarynowe } \\
\text { Leki } \\
\text { cholinomimety } \\
\text { czne }\end{array}$ & $\begin{array}{l}1-2 \mathrm{mg} \text { iv co } 10-20 \\
\text { minut aż do uzyskania } \\
\text { objawów atropinizacji } \\
\text { (szerokie źrenice, } \\
\text { sucha skóra, } \\
\text { tachykardia, } \\
\text { zmniejszona } \\
\text { hipersekrecja } \\
\text { oskrzelowa) }\end{array}$ \\
\hline 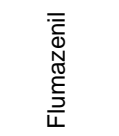 & $\begin{array}{l}\text { Antagonista } \\
\text { receptorów } \\
\text { benzodiazepino } \\
\text { wych }\end{array}$ & $\begin{array}{l}\text { Benzodiazepi } \\
\text { ny }\end{array}$ & $\begin{array}{l}0.2 \mathrm{mg} \text { początkowo } \\
\text { co } 20 \text { minut do max } \\
5 \mathrm{mg}\end{array}$ \\
\hline $\begin{array}{l}\text { ㅁ } \\
\hat{w} \\
\frac{0}{0} \\
\frac{0}{2}\end{array}$ & $\begin{array}{l}\text { Antagonista } \\
\text { receptorów } \\
\text { opioidowych }\end{array}$ & Opioidy & $\begin{array}{l}0.4-2 \text { mg, powtarzać } \\
\text { co } 2 \text { minuty gdy } \\
\text { obserwuje się } \\
\text { poprawę stanu } \\
\text { klinicznego do max } \\
\text { 10mg }\end{array}$ \\
\hline 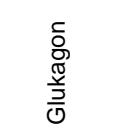 & $\begin{array}{l}\text { Wzrost stężenia } \\
\text { amin } \\
\text { katecholowych }\end{array}$ & $\begin{array}{l}\beta \text {-blokery } \\
\text { Blokery } \\
\text { kanału } \\
\text { wapniowego }\end{array}$ & 5- $10 \mathrm{mg}$ iv \\
\hline 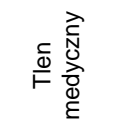 & $\begin{array}{l}\text { Odtrutka } \\
\text { nieswoista }\end{array}$ & $\begin{array}{l}\text { Gazy duszące } \\
\text { chemicznie i } \\
\text { fizycznie }\end{array}$ & $12-15 \mathrm{l} / \mathrm{min} 100 \%$ \\
\hline & & & $24-28$ \\
\hline
\end{tabular}




\section{PIŚMINNICTWO}

1. Stańczyk J. Departament Badań Demograficznych i Rynku Pracy. Podstawowe informacje o rozwoju demograficznym Polski do 2014 roku. Warszawa; Główny Urząd Statystyczny, 2015.

2. Sieńczuk W. Toksykologia współczesna. Warszawa; Wydawnictwo Lekarskie PZWL, 2005.

3. Pach J. Klinika ostrych zatruć dla ratowników medycznych. Nowy Sącz; Wydawnictwo Naukowe Państwowej Wyższej Szkoły Zawodowej w Nowym Sączu, 2011.

4. Burda P. Ostre zatrucia. Med Tribune Pol 2012; 11: 21-26.

5. Burda P. Klinika ostrych zatruć dla ratowników medycznych. Nowy Sącz; Państwowa Wyższa Szkoła Zawodowa w Nowym Sączu, 2011.

6. Badzińska, E. Zatrucia lekami przeciwdepresyjnymi. Post Psychiatr Neurol 1992;1: 295-302.

7. Święcicki, Ł. Ryzyko śmierci z powodu powikłań kadriologicznych po próbach samobójczych z użyciem leków przeciwdepresyjnych. Wiad Psychiatr 2005;4: 217-221.

8. Figura B. Dopalacze - nowa generacja narkotyków syntetycznych. Świat Farm 2010 (11): 46-47.

9. Łukasik - Głębocka M. Nowe syntetyczne środki psychoaktywne - dopalacze. Med Dypl 2013; 22 (7/8): 30 $-36$.

10. Burak K. Farmakologia dla Ratowników Medycznych. Legnica; Wyższa Szkoła Medyczna w Legnicy, 2012.

11. Dart RC, Bronstein AC, Spyker DA, et al. Poisoning In the United States:2012 Emergency Medicine Report of the National Poison Data System. Ann Emerg Med 2014;2:25-34.

12. Katzung BG, Masters SB, Trevor AJ. Farmakologia ogólna i kliniczna. Lublin; Wydawnictwo Czelej, 2012.

13. Zając M, Waldman W. Postępowanie przedszpitalne w ostrych zatruciach. Na ratunek 2015; 2 : 33-44.

14. Janus T, Janus A, Piechocki J. Odtrutki zespołu podstawowego. Nalokson, flumazenil, atropina. Na ratunek 2015; 6 : 21-26. 